\title{
Drivers and Patterns of Supply Chain Collaboration in the Pharmaceutical Industry: A Case Study on SMEs in China
}

\author{
Lin Huang, Yong Lin, Petros Ieromonachou, Li Zhou, Jing Luo \\ The Faculty of Business, University of Greenwich, London, UK \\ Email: L.Huang@gre.ac.uk, Y.Lin@gre.ac.uk, P.leromonachou@gre.ac.uk, Li.Zhou@gre.ac.uk, J.Luo@gre.ac.uk
}

Received 6 April 2015; accepted 28 June 2015; published 1 July 2015

\begin{abstract}
The objectives of this paper are to identify the supply chain collaboration models/patterns and its correspondent advantages on pharmaceutical supply chain. This paper aims to investigate how collaborative activities can impact on the development of supply chain and industry. A case study methodology was adopted in this research, which involved pharmaceutical SMEs. The results indicate that collaborations are common in all phases of pharmaceutical supply chain; the different strength of barging power among collaborative partners will impact the advantages achieved at strategic, operational and political levels.
\end{abstract}

\section{Keywords}

Supply Chain Collaboration, Pharmaceutical Industry, SME, China

\section{Introduction}

In the past decades, academia and business practitioners have realized that achieving efficient supply chain and quick responsiveness to the needs of dynamic markets, and the relationships and interactions within organization and among external environment including government agencies, suppliers and academic institutions are increasingly important to firms seeking to benefits and competitive advantages [1]-[3]. A number of empirical results showed that supply chain collaboration had positive impacts on decision-making, problem-solving, and costsaving [4] [5]. However, the literature on supply chain collaboration is not that wealth, and most of them are not able to fully explain the complexity of the collaborative relationships and seldom consider realistic situations [4]. Further investigation is required to recognize the great potential and value of supply chain collaboration [1].

The pharmaceutical industry is a complex network of organizations involved in drug and medication discovery, development, and manufacture [6] [7]. There are many challenges, such as high cost in research and development (R \& D) stage and the declining R \& D success rate [8]. Government and regulatory institutions tend to intervene with more [6] and increase the pressures in further development. Collaboration as an effective means to tackle those challenges has been practiced in general by many big pharma companies for a long time [7]. However, for other small and medium sized enterprises (SMEs), not many of them have applied strategy as the 
big pharma companies do, although most of them may have realized the need of collaborations to assist them better compete in the market and successfully transfer to a larger scale [9] [10]. Therefore, researches in this area are in urgent need.

As one of the emerging economics, China's pharmaceutical sector is in a significant position in the period of rapid growth of industrialization and urbanization [11]. The pharmaceutical industry in China is largely influenced by government and regulatory institutions in both structure shaping and network building [12] [13]. Those challenges [9] [14]-[16] indicated above also are in a way slowing down China's pharmaceutical industry's pace of progress [17]. To find the way out, strategic collaborations among stakeholders in supply chain are increasingly considered to be able to generate more superiority in current situation [17] [18].

The objective of this paper is to identify the collaboration models/patterns and its related advantages on pharmaceutical supply chain. In the following sections, research questions related to pharmaceutical supply chain collaboration are going to be defined based on literature review; then results generated from case study to answer the questions will be presented; the research contributions, implications, and future directions will be summarized in the conclusion section.

\section{Literature Review}

\subsection{Pharmaceutical Supply Chain}

Supply chain is defined as a series of activities and organizations facilitate material flow from raw materials to final products downstream [19]. Pharmaceutical manufacturer as one the main actors in healthcare supply chain [20], is inevitable to come into contact with other players, like government, regulatory institutions, integrated delivery networks, and other channel members [6] [7] [11] more than only the suppliers and direct customers in pharmaceutical supply chain. However, studies in dyads are mostly focused on downstream network in the pharmaceutical manufacturing and distribution sectors, and the upstream issues are considered separately [21]. An efficient pharmaceutical supply chain cannot count on the stand-alone effort of any individual participant [5], but to collaborate with independent players to approach the common goal [4] in the changing market conditions.

\subsection{Outsourcing in Pharmaceutical Industry}

Outsourcing organizational activities to outside vendors may gain competitive advantages of cost-saving and resource-leverage [22] [23]. Pharmaceutical manufacturers are usually treaded as "innovative enterprise" [8] facing significant challenges of ensuring sufficient investment in R \& D [24], hence they tend to outsource some "noncore" activities [9]. However, outsourcing has applied not only to "noncore" activities, the core activities of R \& D [20] [23] [25], manufacturing [20] [21] [26], and logistics [9] [27] [28] have been involved as well. This may lead to a need of close collaboration with public science [25] [29] or even flexible strategic alliance with peer competitors [29] [30]. The collaborations in supply chain is indispensable [32] [33], and the strategic alliance in outsourcing can help pharmaceutical organizations to achieve a sustainable development, if done properly.

Question One: How does collaboration between focal company and outsourcing provider impact on pharmaceutical supply chain?

\subsection{Collaboration in Pharmaceutical Supply Chain}

Supply Chain collaboration as the key to create value emphases on governance through relational means and contract means [1], enables partners to jointly gain sustainable benefits [34]. In pharmaceutical supply chain, the main players who directly associate with pharmaceutical manufacturer are material (medical) suppliers, wholesalers, order distributors (3PLs), competitors, customers (hospitals and physicians), academia (university and research institutions), government, and regulatory institutions [3] [13] [17] [20] [35] [36]. In addition, the outsourcing of manufacturing [25] and acquisition of partners may introduce subcontract partners and subsidiaries into the group.

The creation of alliance can be driven by motivations [33] of cost-reduction [37] [38], supply chain flexibility [22], sustainability [39], and future opportunity [6] [40]. In addition to this, as the increasingly intervene come from government and regulatory institutions [6], it is necessary to maintain a good relationship with the political players, in order to get related support for expansion and better development. The possible collaborations are kind of tied to the running of business [41], at the level of operation, strategy, and policy. In the previous re- 
searches, the complexity of dyadic collaborative relationship are not fully discovered [4], there is no related references of collaborative modes/patterns.

Question Two: How do different collaboration modes/patterns impact on pharmaceutical supply chain?

\subsection{Conceptual Framework}

In summary, ten dyadic relationships between the focal company (pharmaceutical manufacturer) and possible partners (material supplier, wholesaler, 3PL, competitor, customer, academia, government, regulatory institution, subcontractor, subsidiary) will be investigated in according to the factors/motivations of cost-reduction, flexibility, sustainability, opportunity, and policy \& regulation. Moreover, as creation of collaborations stick to business running in the level of operation, strategy and policy [41]; further analysis is based on it.

\section{Research Methodology}

\subsection{Case Study and Data Collection}

Research questions proposed here are mainly about "how", a case study methodology is preferred for this research [42]. Multiple-case studies are adopted to investigate certain phenomenon in details rather than in general [36] [43]. The three chosen case companies are all SMEs and the parent companies of three cases are located in the same district. Multiple sources of evidence are used to address validity issues [44]. Data collection was collected via interviews, questionnaires in two stages (Table 1). In stage one, a 1 - 2 hours interview were taken with the top managers and then department managers. In stage two, a questionnaire are generated and send to them for further detailed information.

\subsection{Summary of the Case Study Results}

As shown in Table 2, the ten identified dyadic relations have been confirmed in PM-1 and PM-2, but in PM-3 only seven relation modes exist in business. Due to PM-3 is a pharmaceutical focus on Chinese Patent Medicines, the number of related business practitioners are comparatively not many. The product category is less and production scale is rather small. Thus, the test result [44] is understandable and acceptable.

Table 1. Data collection.

\begin{tabular}{|c|c|}
\hline Data Collection & Stage 2 \\
\hline $\begin{array}{c}\text { Case } \\
\text { Company }\end{array}$ & $\begin{array}{l}\text { Pharmaceutical Manufacturer } 1 \text { (PM-1): PM-1 is one of the listing companies in SZSC (Shenzhen Stock Exchange) ChiNext Board. } \\
\text { As a leading and professional SME in pharmaceutical, their sales network covers more than } 30 \text { provinces in China. } \\
\text { Pharmaceutical Manufacturer } 2 \text { (PM-2): PM-2 is a professional pharmaceutical SME is currently preparing for stock market listing. } \\
9 \text { GMP (Good Manufacturing Practice) plants with more than } 500 \text { employees serve more than } 20 \text { provinces in China. } \\
\text { Pharmaceutical Manufacturer } 3 \text { (PM-3): PM-3 is a pharmaceutical SME which is mainly engaged in the development, production, } \\
\text { and sales of Chinese Patent Medicines. Their products are not only serving to China local markets, but also sell to Malaysia, Singa- } \\
\text { pore, and other districts in the world. }\end{array}$ \\
\hline
\end{tabular}

Table 2. Dyadic relations of case company and partners.

\begin{tabular}{|c|c|c|c|c|c|c|c|c|c|c|}
\hline \multirow{2}{*}{ 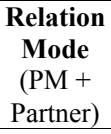 } & R-1 & $\mathrm{R}-2$ & $\mathrm{R}-3$ & $\mathrm{R}-4$ & $\mathrm{R}-5$ & $\mathrm{R}-6$ & $\mathrm{R}-7$ & R-8 & R-9 & $\mathrm{R}-10$ \\
\hline & $\begin{array}{l}\text { Material } \\
\text { Supplier }\end{array}$ & Wholesaler & $3 \mathrm{PL}$ & Competitor & Customer & Academia & Government & $\begin{array}{l}\text { Regulatory } \\
\text { Institution }\end{array}$ & Subcontractor & Subsidiary \\
\hline PM-1 & & & $\begin{array}{c}\mathrm{PO} \\
(\text { Logistics, }>50 \%)\end{array}$ & PO (R \& D) & & PO (R \& D) & & & PO (R \& D) & \\
\hline \multirow[b]{2}{*}{ PM-2 } & $\sqrt{ }$ & $\sqrt{ }$ & $\sqrt{ }$ & $\sqrt{ }$ & $\sqrt{ }$ & $\sqrt{ }$ & $\sqrt{ }$ & $\sqrt{ }$ & $\sqrt{ }$ & $\sqrt{ }$ \\
\hline & & & $\begin{array}{c}\text { PO } \\
(\text { Logistics, }>90 \%)\end{array}$ & PO (Sales) & & $\mathrm{PO}(\mathrm{R} \& \mathrm{D})$ & & & $\mathrm{PO}(\mathrm{R} \& \mathrm{D})$ & \\
\hline \multirow{2}{*}{ PM-3 } & $\sqrt{ }$ & $\sqrt{ }$ & $\sqrt{ }$ & - & $\sqrt{ }$ & $\sqrt{ }$ & $\sqrt{ }$ & $\sqrt{ }$ & - & - \\
\hline & & & $\begin{array}{c}\text { FO } \\
\text { (Logistics, } \approx 100 \% \text { ) }\end{array}$ & & & $\mathrm{PO}(\mathrm{R} \& \mathrm{D})$ & & & & \\
\hline
\end{tabular}

PO: Partly Outsourced; FO: Fully Outsourced. 


\section{Analysis and Findings}

\subsection{Collaboration in Outsourcing}

The research results indicated that the activities frequently outsourced in China's pharmaceutical industry are $\mathrm{R}$ \& D and Logistics. The forms of R \& D outsourcing are mainly commissioned and joint researches with research institutions or competitors in pharmaceutical manufacturing. Usually, R \& D outsourcing occurs when sufficient fund is guaranteed [32] in big pharma, however, in China's market, SMEs tend to partly outsource R \& D in order to achieve "sustainability, opportunity" for business and even "cost-saving" for supply chain operation. To ensure the mutual benefits, focal company tends to consider possible partner in many aspects, such as "expertise and experience", "references" and "industry vision" [41]. The formed relationship is more than "buyer-supplier", but alike members of same level in alliance.

The outsourcing of logistics has becoming a key component in pharmaceutical supply chain development, focal companies tend to outsource the distribution function to 3PLs. Different from big Pharma in developed market [38], the logistics outsourcing is not at a strategic level [28], as not many of SMEs in China currently would like to outsource inventory management or other activities associated with their sustainability or opportunity, reasons are the costs and lack of sufficient professional 3PLs, the collaboration decision is still on the operational level to realize "cost-saving" and flexibility in response to the market demand ("flexibility"). Although focal company counts heavily on their 3PL partners, as the "switching costs" are low, in such collaborative relationship, the barging power of pharmaceutical manufacturer is higher.

\subsection{Collaborative Relation Modes in Pharmaceutical Supply Chain}

The creating of collaborative relations is motivated by factors in considerations in different levels [41]. And in research market, collaborations exist in all pharmaceutical supply chain phases, relation modes addressed in specific phases are expected to achieve related advantages. "Guanxi networking" in China is described as channels to acquire resources, information, and knowledge, which could help to enhance predetermined performance and to boost future business [45] is similar to the collaborative relation in achieve mutual benefits.

In particular, the importance of networking with "officials" like government and regulatory institutions [45] can be seen, although sometimes it cannot bring about direct benefits in short term. If focal companies tend to build collaboration in strategic level which focus on both "sustainability" and "opportunity", usually, the advantages can be obtained in operational level is limited; as their barging power is weakened in a certain degree in business. The collaborative relation with Academia is more alike is able to achieve all identified advantages with less risks in moral hazard and completions [32].

\subsection{Impacts/Advantages of Collaborations on Pharmaceutical Supply Chain}

When the barging power of partners in dyadic strategic collaboration is general equilibrium, the formation of alliance enable pharmaceutical manufacturer to obtain opportunities to access resources, knowledge, and information in largest possibility; both focal company and collaborative partner can expect a sustainable development in a long term. When the barging power is disequilibrium, the collaborative relationship between partners are more alike "buyer-supplier", and focal companies usually on achieving realistic benefits like "cost-saving" and "Flexibility", which make the collaborative relation transferred from strategic level to operational level. It is interesting to see when the barging power of alliance member is general equilibrium; the possibility to gain "costsaving" is somehow decreased, while the flexibility can be "guaranteed". For certain expected cost-saving may be required to satisfy in "channel" maintaining. Advantages of fund-support and policy/regulation-support is limited in "cost-reduction", the increasingly required level in manufacturing even borne focal company in resource leverage. The flexibility in response to market requirement and industry development is not high. SMEs are sensitive to any political actions in order to seek opportunities for sustainable development.

One possible collaborative relation between focal company and consultants [41] was not involved in analysis. Although it is said that there is potential of consultancies in China, for the professional consultant team can be expected to help organizations better dealing with problems in supply chain and bring about long-term benefits from the process of planning; the costs to invite professional team is in a way block many SMEs to seek collaborations. 


\section{Conclusion}

This research identified supply chain collaboration modes at strategic, operational, and political levels. For the contribution to supply chain management, this research concludes more existing collaborative patterns rather than general patterns from the view of "supplier-customer", and all of them are addressed in different phases of supply chain. For the contribution of pharmaceutical industry, the patterns and the impacts identified are in a way enabling enterprise to better understand the business relationship with their partners. The main limitation of the research is that only 3 case studies are involved. In the future, empirical research in this topic could be extended to other country backgrounds to conduct comparative studies.

\section{References}

[1] Cao, M. and Zhang, Q. (2011) Supply Chain Collaboration: Impact on Collaborative Advantage and Firm Performance. Journal of Operation Management, 29, 163-180. http://dx.doi.org/10.1016/j.jom.2010.12.008

[2] Liao, S.-H. and Kuo, F.-K. (2014) The Study of Relationships between the Collaboration for Supply Chain, Supply Chain Capabilities and Firm Performance: A Case of the Taiwan's TFT-LCD Industry. International Journal of Production Economics, 156, 295-304. http://dx.doi.org/10.1016/j.ijpe.2014.06.020

[3] Kafouros, M., Wang, C., Piperopoulos, P. and Zhang, M. (2015) Academic Collaborations and Firm Innovation Performance in China: The Role of Region-Specific Institutions. Research Policy, 44, 803-817. http://dx.doi.org/10.1016/i.respol.2014.11.002

[4] Montoya-Torres, J.R. and Ortiz-Vargas, D.A. (2014) Collaboration and Information Sharing in Dyadic Supply Chain: A Literature Review over the Period 2000-2012. Estudios Gerenciales, 30, 343-354. http://dx.doi.org/10.1016/j.estger.2014.05.006

[5] Ramanathan, U. (2014) Performance of Supply Chain Collaboration-A Simulation Study. Expert Systems with Applications, 41, 210-220. http://dx.doi.org/10.1016/j.eswa.2013.07.022

[6] Shah, N. (2004) Pharmaceutical Supply Chains: Key Issues and Strategies for Optimization. Computers and Chemical Engineering, 28, 929-941. http://dx.doi.org/10.1016/j.compchemeng.2003.09.022

[7] Forster, S.P., Stegmaier, J., Spyher, R. and Seeger, S. (2014) Virtual Pharmaceutical Companies: Collaborating Flexibly in Pharmaceutical Development. Drug Discovery Today, 19, 348-355. http://dx.doi.org/10.1016/i.drudis.2013.11.015

[8] Laínez, J.M., Schaefer, E. and Reklaitis, G.V. (2012) Challenges and Opportunities in Enterprise-Wide Optimization in the Pharmaceutical Industry. Computers and Chemical Engineering, 47, 19-28. http://dx.doi.org/10.1016/j.compchemeng.2012.07.002

[9] Rees, H. (2011) Supply Chain Management in the Drug Industry. John Wiley \& Sons, Inc.

[10] Koh, R., Schuster, E.W., Chackrabarti, I. and Bellman, A. (2003) White Paper: Securing the Pharmaceutical Supply Chain. Auto-ID Centre, Mit-AutoID-WH-21.

[11] Yu, X., Li, C., Shi, Y. and Yu, M. (2010) Pharmaceutical Supply Chain in China: Current Issues and Implications for Health System Reform. Health Policy, 97, 8-15. http://dx.doi.org/10.1016/j.healthpol.2010.02.010

[12] The State Council of the People's Republic of China (2012) The Twelfth 5-Year Healthcare Development Plan of China. http://www.gov.cn

[13] Yu, Y., Ma, Z., Hu, H. and Wang, Y. (2013) Local Government Policies and Pharmaceutical clusters in China. Journal of Science and Technology Policy Management, 5, 41-58. http://dx.doi.org/10.1108/JSTPM-02-2013-0004

[14] Huang, S. (2012) How Can Innovation Create the Future in a Catching-Up Economy? Focusing on China's Pharmaceutical Industry. Journal of Knowledge-Based Innovation in China, 4, 118-131. http://dx.doi.org/10.1108/17561411211235721

[15] PricewaterhouseCoopers (2007) Pharma 2020: The Vision Which Path Will You Take? Pharmaceutical and Life Sciences. http://www.pwc.com/gx/en/pharma-life-sciences/pharma-2020/pharma-2020-vision-path.jhtml

[16] Meng, Q., Cheng, G., Silver, L., Sun, X., Rehnberg, C. and Tomason, G. (2005) The Impact of China's Retail Drug Price Control Policy on Hospital Expenditures: A Case Study in Two Shandong Hospitals. Health Policy and Planning, 20, 185-196.

[17] Zhang, M., Pawar, K.S., Shah, J. and Mehta, P. (2012) Evaluating Outsourcing Partners' Capability: A Case Study from the Pharmaceutical Supply Chain. Journal of Manufacturing Technology Management, 24, 1080-1101. http://dx.doi.org/10.1108/JMTM-02-2012-0023

[18] Abudul-Halim, H., Ahmad, N.H. and Ramayah, T. (2015) Unveiling the Motivation to Outsource among SMEs. Busi- 
ness Strategy Series, 13, 181-186. http://dx.doi.org/10.1108/17515631211246258

[19] Bales, R.R., Maull, R.S. and Radnor, Z. (2004) The Development of Supply Chain Management within the Aerospace Manufacture. Supply Chain Management: An International Journal, 9, 250-255. http://dx.doi.org/10.1108/13598540410544944

[20] Pedroso, M.C. and Nakano, D. (2009) Knowledge and Information Flows in Supply Chains: A Study on Pharmaceutical Companies. International Journal of Production Economics, 122, 376-384. http://dx.doi.org/10.1016/j.ijpe.2009.06.012

[21] Narayana, S.A., Pati, R.K. and Vrat, P. (2014) Managerial Research on the Pharmaceutical Supply Chain-A Critical Review and Some Insights for Future Directions. Journal of Purchasing and Supply Management, 20, 18-40. http://dx.doi.org/10.1016/j.pursup.2013.09.001

[22] Scherre-Rathje, M., Deflorin, P. and Anand, G. (2014) Manufacturing Flexibility through Outsourcing: Effects of Contingencies. International Journal of Operations and Production Management, 34, 1210-1242. http://dx.doi.org/10.1108/IJOPM-01-2012-0033

[23] Boulaksil, Y. and Fransoo, J.C. (2010) Implications of Outsourcing on Operations Planning: findings from the pharmaceutical industry. International Journal of Operations and Production Management, 30, 1059-1079. http://dx.doi.org/10.1108/01443571011082526

[24] Sousa, R.T., Shah, N. and Papageorgiou, L.G. (2005) Global Supply Chain Network Optimisation for Pharmaceuticals. Computer Aided Chemical Engineering, 20, 1189-1194. doi:10.1016/S1570-7946(05)80040-9

[25] Scarlett, J.A. (1996) Outsourcing Process-Development and Manufacturing of rDNA-Derived Products. Trends in Biotechnology, 14, 239-244. http://dx.doi.org/10.1016/0167-7799(96)10032-9

[26] Agarwal (2012) Chemistry and Integrated Services in Emerging Countries: How Is the Pharmaceutical Value Chain Changing with Companies Demanding Chemistry and a Provider in Emerging Countries and What Are Suppliers Doing to Upgrade the Offerings and Mitigate the Business Risk? Drug Discovery Today, 17, 1251-1253. http://dx.doi.org/10.1016/j.drudis.2012.09.005

[27] Zhou, E.Y. (2007) China Today-Pharmaceutical Distribution in China: The Country Strive to Modernize Its Distribution Logistics as Thousands of Small Companies Compete for Profits. Biopharm International, 20, 8-24.

[28] Azzi, A., Persona, A., Sgarbossa, F. and Bonin, M. (2013) Drug Inventory Management and Distribution: Outsourcing Logistics to Third-Party Providers. Strategic Outsourcing: An International Journal, 6, 48-64. http://dx.doi.org/10.1108/17538291311316063

[29] Lim, K. (2004) The Relationship between Research and Innovation in the Semiconductor and Pharmaceutical Industries (1981-1997). Research Policy, 33, 287-321. http://dx.doi.org/10.1016/j.respol.2003.08.001

[30] Takayama, M., Watanabe, C. and Griffy-Brown, C. (2002) Alliance Strategy as a Competitive Strategy for Successively Creative New Product Development: The Proof of the Co-Evolution of Creativity and Efficiency in the Japanese Pharmaceutical Industry. Technovation, 22, 607-614. http://dx.doi.org/10.1016/S0166-4972(01)00062-1

[31] PricewaterhouseCoopers (2012) Ensuring Pharmaceutical Supply Chain Effectiveness. Pharmaceutical and Life Sciences. http://www.pwc.com/gx/en/pharma-life-sciences/supply-chain-effectiveness/index.jhtml

[32] Spithoven, A. and Teirlinck, P. (2015) Internal Capabilities, Network Resources and Appropriation Mechanisms as Determinants of R \& D Outsourcing. Research Policy, 44, 711-725. http://dx.doi.org/10.1016/j.respol.2014.10.013

[33] Baloh, P., Jha, S. and Awazu, Y. (2008) Building Strategic Partnerships for Managing Innovation Outsourcing. Strategic Outsourcing: An International Journal, 1, 100-121. http://dx.doi.org/10.1108/17538290810897138

[34] Sahay, B.S. (2003) Supply Chain Collaboration: The Key Value Creation. Work Study, 52, 76-83. http://dx.doi.org/10.1108/00438020310462872

[35] Hira, A. (2009) The Political Economy of the Global Pharmaceutical Industry: Why the Poor Lack Access to Medicine and What Might Be Done about It. International Journal of Development Issues, 8, 84-101. http://dx.doi.org/10.1108/14468950910997666

[36] Conle, M. and Taube, M. (2010) Regional Specialization in China's Biopharmaceutical Industry. Chinese Management Studies, 4, 339-359. http://dx.doi.org/10.1108/17506141011094136

[37] Lau, K.H. and Zhang, J. (2006) Drivers and Obstacles of Outsourcing Practices in China. International Journal of Physical Distribution and Logistics Management, 36, 776-792. http://dx.doi.org/10.1108/09600030610714599

[38] Größler, A., Laugen, B.T., Arkader, R. and Fleury, A. (2013) Differences in Outsourcing Strategies between Firms in Emerging and Developed Markets. International Journal of Operation and Production Management, 33, $296-321$. http://dx.doi.org/10.1108/01443571311300791

[39] Elango, B. (2008) Using Outsourcing for Strategic Competitiveness in Small and Medium-sized Firms. Competitiveness Review: An International Business Journal, 18, 322-332. http://dx.doi.org/10.1108/10595420810920806 
[40] Rapp, A. (2009) Outsourcing the Sales Process: Hiring a Mercenary Sales Force. Industrial Marketing Management, 38, 411-418. http://dx.doi.org/10.1016/j.indmarman.2009.03.006

[41] Whitworth, M. (2005) Outsourced Security—The Benefits and Risks. Network Security, 2005, 16-19. http://dx.doi.org/10.1016/S1353-4858(05)70292-0

[42] Yin, R.K. (2012) Applications of Case Study Research. 3rd Edition, SAGA Publication, Inc.

[43] Yin, R.K. (2014) Case Study Research: Design and Methods. 5th Edition, SAGA Publications, Inc.

[44] Herriott, R.E. and Firestone, W.A. (1983) Multisite Qualitative Research: Optimizing Description and Generalizability. Education Researcher, 12, 14-19.

[45] Chung, H.F.L., Yang, Z. and Huang, P. (2015) How Does Organizational Learning Matter in Strategic Business Performance? The Contingency Role of Guangxi Networking. Journal of Business Research, 68, 1216-1224. http://dx.doi.org/10.1016/j.jbusres.2014.11.016 